\title{
Electronic Toll Collection Systems and their Interoperability: The State of Art
}

\author{
Javier de las Heras Molina \\ Investigador predoctoral. TRANSyT - Universidad Politécnica de Madrid. España \\ Juan Gómez Sánchez \\ Investigador predoctoral. TRANSyT - Universidad Politécnica de Madrid. España \\ José Manuel Vassallo Magro \\ Profesor Titular de Universidad. TRANSyT - Universidad Politécnica de Madrid. España
}

\begin{abstract}
The European Electronic Toll Service (EETS) was created in 2004 with the aim of ensuring interoperability among the existing electronic toll collection (ETC) systems in Europe. However, the lack of cooperation between groups of stakeholders has not made possible to achieve this goal ten years later. The purpose of this research is to determine the better way to achieve interoperability among the different ETC systems in Europe.
\end{abstract}

Our study develops a review of the six main ETC systems available worldwide: Automatic Number Plate Recognition (ANPR), Dedicated Short-Range Communications (DSRC), Radio Frequency Identification (RFID), Satellite systems (GNSS), Tachograph, and Mobile communications tolling systems. The research also provides some insight on different emerging technologies. By focusing on different operational and strategic aspects offered by each technology, we identify their main strengths, weaknesses, opportunities and threats and makes different recommendations to improve the current framework.

The research concludes that given the diversity of advantages and inconveniences offered by each system, the selection of a certain ETC technology should also take into account its potential to overcome the weaknesses in the current ETC framework. In this line, different policy recommendations are proposed to improve the present ETC strategy at the EU.

\section{INTRODUCTION}

In the EU, road user charges are levied in 22 Member States (Carpintero, 2010) (Hamilton and Eliasson, 2012). The objective of these national tolling systems is to raise revenue to fund the maintenance and expansion of transport networks (Chatterjee, 1999). Around 60\% of the European road infrastructure that is charged $(72,000 \mathrm{~km})$ is equipped with electronic toll collection (ETC) systems (Jou et al., 2013). The problem is these national systems are often not interoperable with other technologies (Innovations, 2006) (de Palma and Lindsey, 2011). This lack of interoperability has set barriers to the flows of goods and people.

In order to remedy this fragmentation and simplify the internal market, the EU passed Directive 2004/52/EC whereby the European Electronic Toll Service was defined. The EETS is intended to enable road users to pay tolls throughout the EU through a contract with a single EETS Service Provider and with one single on-board unit (OBU). To achieve this goal, the Directive requires that all new electronic toll systems shall use one of these three systems: DSRC, GNSS or GSM-GPRS (Nowacki and Niedzicka, 2009). EETS should have been offered all other types of vehicles by 2014; however their deployment remains an issue. Three main stakeholders are identified within the EETS model: users, EETS providers and toll chargers (European Commission, 2012). 
Previous research on ETC systems has been generally focused on measuring the performance of specific technologies on partial aspects (Caneschi, 2007). There is hence a need of an overall evaluation regarding the suitability and opportunities offered by all the alternatives available. To our knowledge, this crucial analysis has not been previously reviewed in the literature. The aim of this paper is to review current and future technological options for ETC systems. To that end, we analyse different aspects of ETC systems influencing the decision-making process of a tolling technology. We discuss the strengths and weaknesses of technologies currently in use, and analyse the on-going developments. Additionally, this research evaluates the performance of the ETC system in the EU and makes different recommendations to improve the framework for the future.

\section{CURRENT TECHNOLOGY OPTIONS}

The main electronic toll collection systems currently in use worldwide are:

Automatic Number Plate Recognition (ANPR), a mature technology using video cameras for vehicle identification, both in urban areas and interurban roads. This system works through cameras (mounted on poles or gantries) taking a picture of the licence plates as the vehicle drives through the detection point. The user is then charged without the need to install any OBU, only requires registering the car in the system and creates a payment account. ANPR has proved to be a useful technology for enforcement purposes. Regarding the accuracy of this technology, the most advanced cameras currently achieve an automatic read rate up to $99 \%$ when mounted on gantries over unidirectional carriageways. ANPR technologies implemented have usually shown a high cost-effectiveness (Prud'homme and Bocarejo, 2005) with annual net revenues being similar or higher than initial investment costs. However, the need to keep the national vehicle and driver registration database up-todate, and the lack of harmonisation of licence plate may increase operational costs.

Dedicated short-range communications technologies (DSRC), based on bidirectional radio communication between fixed roadside equipment (RSE) and on-board units (OBU) installed in a vehicle (Jordán et al., 2003) (Sorensen and Taylor, 2005). It has been the most common approach to implementing ETC on toll roads since late 1980s (nowadays its accuracy tends towards 100\%). Its applications have been extended to pricing schemes in urban areas and nationwide truck tolling systems (Nowacki et al., 2011). DSRC is often complemented sensors and cameras for enforcement purposes. DSRC can be used either in toll plazas (Pickford and Blythe, 2006), or in multi-lane free flow schemes (Lee et al., 2008) (Sheehan, 2008). The decision on the gantries location may be related with diverse criteria, like the maximization of the profit, the impacts on the local mobility and economy, and the characteristics of the alternative routes (Amorim et al., 2014). DSRC is especially profitable when the tolling scheme is used by many vehicles and few road segments need to be covered (Q-FREE, 2013), because DSRC needs cheap OBUs and expensive RSE.

Radio Frequency Identification (RFID), the most used toll collection system in the United States and China, relying on radio waves to identify on-board devices. The performance and characteristics of RFID approaches are, at least in practice, very similar to those of DSRC technology (can be less accurate than DSRC), since both are microwave-based approaches (Feng et al., 2010) (Ren and Gao, 2009).

Global Navigation Satellite Systems (GNSS) involves the vehicle's position data being used to measure the use of the road in order to calculate the charge. This technology requires 
the use of: a GNSS OBU that records the vehicle's movements by downloading satellite time-stamped location, mobile data communications equipment, and a back office (Jordán et al., 2003) (Händel et al., 2014). The most significant strengths of GNSS technology are its limited need for roadside equipment and its flexibility. GNSS-based enforcement is similar to the DSRC-based approach. The fraud rate experienced by this technology is lower than $2 \%$ (Fuente et al. 2011). The level of satellite visibility is the main parameter that determines the accuracy of the GNSS-based ETC system. Data privacy is also a critical issue because of the amount of personal information collected. GNSS-based tolling systems are more suitable for area-wide tolling, because if the network expands, marginal costs will be lower than other technologies. Finally, the GNSS-based system has succeeded in achieving interoperability with other existing tolling schemes.

Tachograph-based tolling, recording the mileage driven by the user through an OBU connected electronically to the vehicle's odometer. It is not commonly used (only in Switzerland and Oregon). Tachograph technology is based on user's self-declaration, and data recordings must be periodically sent to the tolling authorities (Felix and Neuenschwander, 2002). Evasion rates are below 1\% according to Balmer (2006), but it has a lower accuracy than other systems (Engdahl, 2013). Issues of data protection and user privacy are avoided in this system. Cost-efficiency depends on the RSE installed. In addition, the price of the OBU is higher than other TAGs (Oehry, 2010; FCA, 2013).

Mobile communication (GSM and smartphone) tolling systems are still in an embryonic stage but having significant potentials going forward. The combination of mobile phone penetration, technological progress in NFC and growing cellular network coverage let integrate mobile phones with ETS, with higher flexibility to pay the toll, and transparency to check payments. This technology reduces initial investments and operating costs, since no OBUs and gantries are needed. It also appears as an accurate technology, which improve interoperability. However, some issues still need to be addressed such as checking vehicle classification, battery life and data protection (Burden and Nijhuis, 2012).

\section{THE FUTURE: TOWARDS INTEGRATED DEVICES}

In order to foresee the future development of EETS, it is necessary to provide some insight regarding emerging technologies potentially useful for tolling (McKinnon, 2006). Opportunities may come from emerging technologies, such as Cooperative Vehicle Information Systems (CVIS), an information-sharing platform for intelligent transportation system organization (Ding, 2014), and Communications Access for Land Mobile (CALM) areas, which provide wireless communications; applications such as telematics for vehicle and driver management, eCall (Ingenico, 2013) (Öörni and Korhonen, 2014) (Pascale et al., 2015) or usage-based insurance (UBI), under which insurance fees could be determined based on driving behaviour (Händel et al., 2014); and communication technology at $5.9 \mathrm{GHz}$ (Mcnew, 2010) (Ansari et al., 2013), among others. Substantial advances are also expected in payment methods. Contactless payments through a mobile phone using NFC allow better cashless transactions. By using NFC technology, smartphones will facilitate the switch to all-electronic toll collection.

\section{COMPARATIVE AND SWOT ANALYSES OF ETC TECHNOLOGIES}

This section compares different ETC technologies previously described. Costs evaluation, interoperability, accuracy, data protection, enforcement and obsolescence were taken into 
consideration for the analysis. Finally, we conducted a SWOT analysis (see table 1).

The cost of installing and subsequently operating a tolling system is among the most significant issues affecting the development of EETS. This aspect can vary significantly across ETC options, mainly due to: the roadside equipment, OBU and enforcement actions required by each technology. Regarding roadside equipment, the usual DSRC and RFID systems require the installation of costly gantries, and significant capital investment will be needed to cover the road network correctly. By contrast, GNSS and GSM options are less costly from the infrastructure point of view. With regard to the OBU used, technologies such as ANPR, mobile phone and smartphone-based tolling do not require in-vehicles devices. Other technologies such as DSRC and GNSS require OBUs devices which may represent an important cost for drivers, especially in the tachograph-based system. The cost of enforcement purposes could be reduced by implementing a Pan-European vehicle and driver register and common standards for evidences. The main advance is expected in payment methods with digital channels based on internet, without main privacy problems.

One of the most important problems related to ETC system is the lack of trans-national interoperability observed in the EU. The main opportunities and challenges in the EU lie on the adoption of common and interoperable technologies among Member States. DSRC technology presents several threats due to DSRC OBU limitations. In addition, more than 10 million OBUs are already in operation in Europe, so changing all these units would imply a significant cost. However, GNSS technology is well-placed to ensure interoperability although the technology is not widespread. Opportunities to improve interoperability may come from emerging technologies or applications. Bringing these technologies together into "one box" would have a significant impact on interoperability.

Achieving a high accuracy rate in toll collection is among the main concerns for road operators. DSRC shows the best performance, since its failure rate is generally below 0.1 $\%$. Regarding GNSS technology, further developments in satellite coverage are expected to improve the performance of GNSS significantly. ANPR is not limited to operate at certain speeds or greater volumes of traffic due to the advanced development of camera technology, achieving reading rates up to $99.5 \%$. By contrast, GSM is not still a mature technology so various issues will have to be addressed to guarantee a high accuracy level. The development of ETC systems will provide massive amounts of detailed, personal and identification data. Road user privacy is a critical factor. It can deter drivers from adopting OBUs, despite of their advantages (Ogden, 2001; Iqbal \& Lim, 2008). Privacy may pose extra costs to service providers if common standards are adopted (Balasch et al., 2010).

Toll evasion may cause a significant loss of revenue to toll road operators. This issue would be much better managed through the sharing of data on registration and evasion through a secure European registration database (Tren, 2006). However, free flow ETC technologies still require the implementation of reliable enforcement mechanisms to identify toll violators and guarantee the payment of tolls. The most appropriate technology for enforcement is ANPR; a flexible system that has been frequently combined with other ETC options (Hsu et al., 2013). The use of ETC technologies for enforcement should be complemented with human resources, such as police controls (Institute for Road Safety Research 2014). Finally, it is strongly advisable that EU authorities standardize different national enforcement laws and create a specific European legislation.

To assess which ETC technologies could play a role in the future, it is important to 
Table 1. SWOT analyses

\begin{tabular}{|c|c|c|c|c|}
\hline TECHNOLOGY & STRENGTHS & WEAKNESSES & OPPORTUNITIES & THREATS \\
\hline DSRC & $\begin{array}{l}\text { - Widely adopted, simple and tested } \\
\text { technology. } \\
\text { - CEN standards available. } \\
\text { - High reliability \& performance, low } \\
\text { signal interference (available for } \\
\text { subterranean facilities). } \\
\text { - Inexpensive OBUs and low } \\
\text { operation costs (compared to } \\
\text { GNSS). } \\
\text { - Large number of DSRC OBUs } \\
\text { currently in operation. }\end{array}$ & $\begin{array}{l}\text { - Necessity to install road-side } \\
\text { infrastructure (gantries) along the } \\
\text { road. } \\
\text { - High capex and maintenance cost } \\
\text { of tolling infrastructure. } \\
\text { - Costly to modify the tolled } \\
\text { network once implemented. } \\
\text { - Costly for roads with many } \\
\text { intersections. } \\
\text { - Monitoring gantries take up land } \\
\text { and it is difficult to find space in } \\
\text { non-motorway environments. }\end{array}$ & $\begin{array}{l}\text { - Ability to provide/support other } \\
\text { value-added services through the } \\
\text { OBU. } \\
\text { - Easier interoperability with } \\
\text { existing private concession toll } \\
\text { roads. } \\
\text { - Closer control of the tolling } \\
\text { system and revenues by Member } \\
\text { States. }\end{array}$ & $\begin{array}{l}\text { - The creation of a centralized } \\
\text { tolling system may be extremely } \\
\text { difficult. } \\
\text { - Coordination in electronic } \\
\text { transactions among countries. } \\
\\
\text { - Less profitable in low traffic } \\
\text { volume roads. }\end{array}$ \\
\hline $\begin{array}{c}\text { Satellite-based } \\
\text { (GNSS) }\end{array}$ & $\begin{array}{l}\text { - Flexibility to define and modify } \\
\text { what is to be charged and how is } \\
\text { to be charged. } \\
\text { - Easily expandable to other roads } \\
\text { and regions. } \\
\text { - Scarce necessity to invest in } \\
\text { physical tolling roadside } \\
\text { infrastructure. } \\
\text { - Once installed, less costly to } \\
\text { maintain. }\end{array}$ & $\begin{array}{l}\text { - Higher start-up costs (OBUs, } \\
\text { back-office, etc.) when compared } \\
\text { to other technologies. } \\
\text { - Less used and mature technology } \\
\text { than other options. } \\
\text { - Higher operation costs due to GSM } \\
\text { communication. } \\
\text { - Detailed and careful planning is } \\
\text { needed before starting running } \\
\text { the system. } \\
\text { - Interoperability with existing } \\
\text { tolling schemes needs to be } \\
\text { pursued. }\end{array}$ & $\begin{array}{l}\text { - Possibility to create a single } \\
\text { centralized electronic toll } \\
\text { collection system at the European } \\
\text { level. } \\
\text { - Ability to provide/support other } \\
\text { value-added services through the } \\
\text { OBU: traffic information, speed } \\
\text { control, etc. } \\
\text { - Better performance and accuracy } \\
\text { are expected with the } \\
\text { implementation of the GALILEO } \\
\text { navigation system. } \\
\text { - Interoperability with other tolling } \\
\text { technologies (DSRC) has already } \\
\text { been achieved (TOLL2GO). } \\
\text { - Once implemented, tolling low } \\
\text { traffic volume is less costly. }\end{array}$ & $\begin{array}{l}\text { - Accuracy errors in certain sections } \\
\text { of the tolled network. Satellite } \\
\text { signal may be lost (additional } \\
\text { roadside devices need to be } \\
\text { installed). } \\
\text { - Potential reluctance of Member } \\
\text { States in case a centralized tolling } \\
\text { system is created. } \\
\text { - Data protection is strongly } \\
\text { required due to the amount of } \\
\text { information collected. }\end{array}$ \\
\hline $\begin{array}{c}\text { Mobile } \\
\text { communication } \\
\text { (GSM and } \\
\text { smartphones) }\end{array}$ & $\begin{array}{l}\text { - Flexibility to define and modify } \\
\text { what is to be charged and how is } \\
\text { to be charged. } \\
\text { - Little physical tolling roadside } \\
\text { infrastructure investment. } \\
\text { - No need for in-vehicle device or } \\
\text { costly enforcement infrastructure. } \\
\text { Low maintenance costs. } \\
\text { - Interoperability with other tolling } \\
\text { technologies. }\end{array}$ & $\begin{array}{l}\text { - Device battery duration. } \\
\text { - No proven data about accuracy in } \\
\text { certain sections of the tolled } \\
\text { network. } \\
\text { - Detailed and careful planning is } \\
\text { needed before starting the } \\
\text { system. } \\
\text { - Variable proliferation of Mobile and } \\
\text { smart phones in different areas. }\end{array}$ & $\begin{array}{l}\text { - Possibility to create a single } \\
\text { centralized electronic toll } \\
\text { collection system at EU level. } \\
\text { - Continuous technological } \\
\text { improvements in the sector. } \\
\text { - Possibility to integrate Toll } \\
\text { payment with other user services. }\end{array}$ & $\begin{array}{l}\text { - Data protection issue in relation to } \\
\text { cellular network used to track user } \\
\text { position. } \\
\text { - Potential reluctance of Member } \\
\text { States in case a centralized tolling } \\
\text { system is created. } \\
\text { - Less used \& mature technology } \\
\text { than others (No standards } \\
\text { currently available). } \\
\text { - Can become obsolete very quickly } \\
\text { given technological developments } \\
\text { in the sector. }\end{array}$ \\
\hline
\end{tabular}


understand the degree of obsolescence of current technologies. It occurs due to the availability of alternatives that performs better or are cheaper or both, or due to changes in user preferences, requirements or styles. DSRC shows minimum signs of obsolescence (Lu et al., 2010) (Barbaresso and Johnson, 2014). GNSS is still developing through better signal processing and improved satellite coverage. Given the increasing adoption of ANPR technology for enforcement uses, it is unlikely to become obsolete as a system in the following decades. In contrast, GSM tolling is subjected to significant obsolescence threats due to the rapid technological development (in Europe is now using 4G).

Finally, ETC systems try to offer a better experience and complementary added-value services to users. In that way, mobile phone ETC services and some OBUs can offer a userfriendly experience, flexibility, and easy integration with other technologies and services (Lamy, 2012). However, other technologies, tachograph or ANPR, cannot provide new services to users. Recent technological developments are now pushing intelligent transportation systems (ITS) toward a major leap forward (Papadimitratos et al., 2009).

\section{CONCLUSIONS}

The implementation of EETS has rather been hampered by the lack of cooperation among different stakeholders, the limited efforts done by some EU countries, and different barriers such as technical reasons. Our research yielded some interesting conclusions. The first one is that all the technologies available have significant differences in terms of the opportunities provided in areas such as performance, enforcement, accuracy, cost or obsolescence. The second conclusion refers to the weaknesses identified in the current ETC framework, because ETC systems and their enforcement have not yet been widely incorporated by drivers and authorities at the international level. Based on this analysis, we point out different policy recommendations to improve the current ETC framework. Firstly, a generalized introduction of ETC devices should be promoted. This recommendation could be accompanied by the setting up of official standards, regulations and product certifications on electronic devices. Secondly, enacting a transnational mandatory regulation on toll evasion would result really helpful. In addition, to ensure data privacy, an international agreement must be reached.

Some subjects emerge for further research. The definition of life-cycle cost functions for different technologies depending on the characteristics of the network will be of great value to give recommendations about the most suitable technology to be implemented. The definition of a methodology to evaluate the potential benefits of a reaching interoperability at the trans-national level should be evaluated. Finally, a more in-depth study of emerging technologies in comparison with current ETC systems is needed.

\section{REFERENCES}

Amorim, M., Lobo, A., Rodrigues, C., Couto, A., 2014. Optimal Location of Electronic Toll Gantries: The Case of a Portuguese Freeway. Procedia - Soc. Behav. Sci. 111, 880889. doi:10.1016/j.sbspro.2014.01.122

Angelis, M. De, Giorgi, P., 2013. The European Electronic Toll Service: a key strategy for easier mobility in Europe, in: Convegno Nazionale AEIT: Innovation and Scientific and Technical Culture for Development. Mondello, Italy, p. 6.

Ansari, K., Wang, C., Wang, L., Feng, Y., 2013. Vehicle-to-vehicle real-time relative positioning using 5.9 GHZ DSRC media. IEEE Veh. Technol. Conf. doi:10.1109/VTCFall.2013.6692454 
Balasch, J., Rial, A., Troncoso, C., Preneel, B., Verbauwhede, I., Leuven, I.U., Cosic, E., Geuens, C., Leuven, K.U., Leuven, B., 2010. PrETP : Privacy-Preserving Electronic Toll Pricing. 19th USENIX Secur. Symp. 2010 63-78.

Balmer, U., 2006. Kilometer Fee for Heavy Goods Vehicles The Swiss Experience Driver for Introduction : Transit Traffic. Budapest, Hungary.

Barbaresso, J., Johnson, P., 2014. Connected Vehicle Infrastructure Deployment Considerations: Lessons Learned from the Safety Pilot Model Deployment. USA.

Burden, M., Nijhuis, J., 2012. Debating contactless toll charging by smartphone. ITS Int.

Caneschi, F., 2007. CEN STANDARDIZATION OF THE ELECTRONIC TOLL SYSTEMS ARCHITECTURE. Pisa, Italy.

Carpintero, S., 2010. Toll Roads in Central and Eastern Europe: Promises and Performance. Transp. Rev. 30, 337-359. doi:10.1080/01441640903017380

Chatterjee, K., 1999. Modelling the impacts of transport telematics: current limitations and future developments. Transp. Rev. 19, 57-80. doi:10.1080/014416499295673

Commission, E., 2012. The European Electronic Toll Service (EETS) ensures interoperability of road toll systems - frequently asked questions.

Commission, E., 2009. Commission Decision on the definition of the European Electronic Toll Service and its technical elements.

De Palma, A., Lindsey, R., 2011. Traffic congestion pricing methodologies and technologies. Transp. Res. Part C Emerg. Technol. 19, 1377-1399. doi:10.1016/j.trc.2011.02.010

Ding, Z.M., 2014. A Design of Cooperative Vehicle Infrastructure System Based on Internet of Vehicle Technologies. Appl. Mech. Mater. 552, 363-366. doi:10.4028/www.scientific.net/AMM.552.363

Engdahl, J., 2013. Implementation of the EETS in Switzerland. Basel, Switzerland.

Felix, A., Neuenschwander, R., 2002. WP 3: Case Studies Task 3.2: Case Study Switzerland. Basel, Switzerland.

Feng, Z., Zhu, Y., Xue, P., Li, M., 2010. Design and realization of expressway vehicle path recognition and ETC system based on RFID. Proc. - 2010 3rd IEEE Int. Conf. Comput. Sci. Inf. Technol. ICCSIT 2010 7, 86-90. doi:10.1109/ICCSIT.2010.5563803

Fertel, C., Bahn, O., Vaillancourt, K., Waaub, J.P., 2013. Canadian energy and climate policies: A SWOT analysis in search of federal/provincial coherence. Energy Policy 63, 1139-1150. doi:10.1016/j.enpol.2013.09.057

Fuente, B. de la, Rodríguez, J., Rodríguez, A., García, A., Velasco, A., López, J.C., García, J., Santamaría, B., Temboury, M., 2011. La Euroviñeta: Claves para la introducción del pago por uso en España. Madrid, Spain.

Hamilton, C.J., Eliasson, J., 2012. Costs and benefits of the European directive on road tolling interoperability. Transp. Res. Part C Emerg. Technol. 30, 221-238. doi:10.1016/j.trc.2011.09.009

Händel, P., Member, S., Ohlsson, J., Ohlsson, M., Skog, I., Nygren, E., 2014. SmartphoneBased Measurement Systems for Road Vehicle Traffic Monitoring and Usage-Based Insurance 8, 1238-1248.

Hsu, G., Lin, L., Jan, R., Chen, C., 2013. Design of ETC Violation Enforcement System for Non-payment Vehicle Searching. Trans. Adv. Commun. Technol. 2, 169-178.

Ingenico, 2013. Ingenico. Annual Report 2013.

Innovations, T., 2006. The Many Facets of ETC Interoperability, in: ITS World Congress. Institute for Road Safety Research, 2014. Fact sheet Police enforcement and driving speed. Iqbal, M.U., Lim, S., 2008. Designing tolling technologies with privacy in mind: A user perspective. Transp. Res. Part C Emerg. Technol. 61, 1-25. 
Jordán, J.G., Soriano, F.R., Catalá, P., Montes, S., 2003. A STUDY OF ROAD PRICING SYSTEMS BASED ON GNSS / CN.

Jou, R.C., Chiou, Y.C., Kuo, C.W., Tan, H.I., 2013. Freeway drivers' willingness to pay for an on board unit under an electronic toll collection system. Transp. Res. Part C Emerg. Technol. 27, 16-24. doi:10.1016/j.trc.2012.11.002

Kapsch, 2013. Soluciones para el Peaje.

Lamy, B., 2012. 5 . 9 GHZ, WHICH FUTURE IN EUROPE?

Lee, W.H., Tseng, S.S., Wang, C.H., 2008. Design and implementation of electronic toll collection system based on vehicle positioning system techniques. Comput. Commun. 31, 2925-2933. doi:10.1016/j.comcom.2008.05.014

Lu, S., He, T., Gao, Z., 2010. Electronic toll collection system based on global positioning system technology. Int. Conf. Challenges Environ. Sci. Comput. Eng. CESCE 2010 2, 11-14. doi:10.1109/CESCE.2010.147

McKinnon, A.C., 2006. A review of European truck tolling schemes and assessment of their possible impact on logistics systems. Int. J. Logist. Res. Appl. 9, 191-205. doi:10.1080/13675560600859110

Mcnew, J., 2010. 5.9 GHz Tolling Systems.

Nowacki, G., Mitraszewska, I., Kami, T., 2011. THE NATIONAL AUTOMATIC TOLL COLLECTION SYSTEM FOR THE REPUBLIC OF POLAND. Transp. Telecomunicaction 9, 24-38.

Nowacki, G., Niedzicka, A., 2009. Some Problems of the European Electronic Toll Service Interoperability, in: Intelligent Transport Systems. Varsovia, Polonia, pp. 185-192.

Oehry, B., 2010. Swiss Heavy Vehicles Fee LSVA Implementation and Experiences. Basel, Switzerland.

Ogden, K.W., 2001. Privacy issues in electronic toll collection. Transp. Res. Part C Emerg. Technol. 9, 123-134. doi:10.1016/S0968-090X(00)00041-3

Öörni, R., Korhonen, T.O., 2014. eCall minimum set of data transmission - results from a field test in Finland. IET Intell. Transp. Syst. 8, 639-647. doi:10.1049/iet-its.2013.0113

Papadimitratos, P., Fortelle, A.D. La, Paristech, M., Evenssen, K., Asa, Q., 2009. Vehicular Communication Systems : Enabling Technologies, Applications, and Future Outlook on Intelligent Transportation. IEEE Commun. Mag. 84-95. doi:10.1109/MCOM.2009.5307471

Pascale, A., Deflorio, F., Nicoli, M., Dalla Chiara, B., Pedroli, M., 2015. Motorway speed pattern identification from floating vehicle data for freight applications. Transp. Res. Part C Emerg. Technol. 51, 104-119. doi:10.1016/j.trc.2014.09.018

Pickford, A., Blythe, P., 2006. Road User Charging and Electronic Toll Collection, Book.

Prud'homme, R., Bocarejo, J.P., 2005. The London congestion charge: A tentative economic appraisal. Transp. Policy 12, 279-287. doi:10.1016/j.tranpol.2005.03.001

Q-FREE, 2013. Q-FREE annual Report 2013. Trondheim, Norway.

Ren, Z., Gao, Y., 2009. Design of electronic toll collection system in expressway based on RFID. Proc. - 2009 Int. Conf. Environ. Sci. Inf. Appl. Technol. ESIAT 2009 3, 779 782. doi:10.1109/ESIAT.2009.555

Sheehan, R., 2008. Technologies That Complement Congestion Pricing.

Sorensen, P., Taylor, B.D., 2005. Review and Synthesis of Road-Use Metering and Charging Systems. 1-153.

Tren, D.G., 2006. Definition of the EFC Application for the EETS Based on Microwave

Technologies 1-32 